Федор Гайда

Московский государственный

университет им. М.В. Ломоносова

fyodorgayda@gmail.com

https://doi.org/10.18485/ai_godine_ww1.2019.ch11

94(470)"1914/1918

\title{
РУССКИЕ РАДИКАЛЬНЫЕ ЛИБЕРАЛЫ О ЦЕЛЯХ РОССИИ В ПЕРВОЙ МИРОВОЙ ВОЙНЕ
}

Участие России в Первой мировой войне оправдывалось русскими радикальными либералами (прежде всего, кадетами, представителями Конституционно-демократической партии (Партии народной свободы)) исходя из соображений как внешне-, так и внутриполитических. При этом вторые имели приоритетное значение. Война мыслилась как способ закрепления России на новых рубежах, препятствиями к чему выступали Османская, Австро-Венгерская и Германская империи. Одновременно препятствием выступало и российское самодержавие - «внутренние немцы», но радикальные либералы предполагали, что в ходе (или в результате) войны верховная власть вынуждена будет пойти на масштабные уступки, которые приведут к изменению всего политического строя России. Подавляющее большинство кадетов как до войны, так и после ее начала не имело большого интереса к вопросам внешней политики и поддерживало войну по преимущественно внутриполитическим причинам.

Тем не менее, позиция партии по задачам войны была сформулирована в ряде статей и выступлений лидеров кадетов. Основной лидер партии П.Н. Милюков до войны придерживался проантантовской и 
болгарофильской позиции. В самом начале войны он выступил против военной поддержки Сербии, после чего газета «Речь» (основной кадетский рупор, находившийся под контролем Милюкова) была закрыта по распоряжению верховного главнокомандующего великого князя Николая Николаевича. Через несколько дней выход газеты был возобновлен, после чего Милюков изменил свою позицию ${ }^{1}$. Партийный лидер объявил войну справедливой и способной содействовать делу мира. По мнению Милюкова, война велась «за осуществление прав народностей, за восстановление поруганных начал международного права и за создание прочного мира на основе справедливого решения всех накопившихся конфликтов и последующей замены вооруженного мира обязательным посредничеством в случае будущих столкновений». Только эти цели могли оправдать решимость союзников бороться до полной победы, которая позволила бы «предписать» [выделено в тексте - Ф.Г.] противнику условия мирного соглашения ${ }^{2}$.

Хотя «освобождение малых народностей» и провозглашалось «основным лозунгом войны» ${ }^{3}$ политический проект русских либералов имел над-этнический характер. Радикально-либеральные лидеры не выдвигали задачи построения «национального государства». Важным соображением было то, что этносы проживают в пределах, которые зачастую непросто определить, и проведение границ будет чревато межнациональ-

1 Гессен И.В. В двух веках. Жизненный отчет // Архив русской революции. Под ред. И.В. Гессена. Кн. 11. Т. 22. М., 1993. С. 326-328.

2 Милюков П.Н. Цели войны // Ежегодник газеты «Речь» на 1916 год. Пг., 1916. С. 29.

3 Милюков П.Н. Цели войны // Ежегодник газеты «Речь» на 1916 год. С. 56. 
ными конфликтами ${ }^{4}$. Поэтому для большинства национальностей (кроме Польши и Финляндии) кадеты придерживались принципа культурной автономии. Даже украинский федералист М.А. Славинский, в 1915 г. опубликовавший статью в либеральном сборнике «Чего ждет Россия от войны?», утверждал, что любое государство по своей природе не может быть национальным 5 . В результате, решая вопрос о национальных задачах, либеральные публицисты предпочитали рассуждать об экономических интересах и «естественных границах». Милюков выстраивал иерархию внешнеполитических задач, которые соответствовали интересам России: 1) решение судьбы Османской империи; 2) раздел Австро-Венгрии; 3) ослабление Германии; 4) вопрос германских колоний 6 . Разумеется, такие формулировки стали возможны только после вступления Турции в войну в октябре 1914 г.

Экономист М.И. Туган-Барановский самым большим приобретением России в случае победы в войне называл черноморские Проливы ${ }^{7}$. С этим полностью соглашался Милюков, называя это «главнейшей национальной задачей»: это объяснялось торговыми интересами. Простая нейтрализация Проливов была недо-

4 Гайда Ф.А. «Нам предлагают вести наступательную политику польскую, украинскую, еврейскую, а вдруг польская столкнется с еврейской?!» Кадеты и национальный вопрос в западных губерниях Российской империи (1907-1914) // Русский сборник: Исследования по истории России / Ред.-сост. О.Р. Айрапетов и др. Т. XXI. М., 2016. С. 257-271.

5 Славинский М.А. Война и национальный вопрос // Чего ждет Россия от войны? Пг., 1915. С. 113-115.

6 Милюков П.Н. Цели войны // Ежегодник газеты «Речь» на 1916 год. С. 31.

7 Туган-Барановский М.И. Война и народное хозяйство // Чего ждет Россия от войны? С. 23. 
статочной, поскольку в случае любой войны их блокада становилась для России болезненной. При этом Россия сохранила бы торговую нейтрализацию и должна была гарантировать черноморским странам свободный проход военных кораблей через Проливы ${ }^{8}$. Он также отмечал, что раздел Османской империи является наиболее простым из всех вопросов послевоенного устройства, поэтому союзники России должны были бы проявить уступчивость ${ }^{9}$. По мнению Милюкова, Россия также получала право на Великую Армению (до г. Сивас на западе и г. Диарбекир на юге), которая должна была иметь выход на юго-восточное черноморское побережье. При этом такая территория с армянским населением, как Киликия, в зону российских интересов по экономическим и военным соображениям не попадала, а потому о ее присоединении речи не шло. Тем не менее, все армянские земли могли претендовать на территориально-политическую автономию ${ }^{10}$. Милюков признавал права Франции на Сирию, Британии - на Месопотамию, считал необходимым учесть итальянские интересы в Малой Азии, а в Палестине ввести международное управление, обеспечивающее религиозное и этническое разнообразие ${ }^{11}$.

Россия должна была получить Галицию и Угорскую Русь, то есть земли до Карпат и на их западных скло-

8 Милюков П.Н. «Нейтрализация» Дарданелл и Босфора // Вопросы мировой войны. Под ред. М.И. Туган-Барановского. Пг., 1915. С. 532-548; Милюков П.Н. Цели войны // Ежегодник газеты «Речь» на 1916 год. С. 32-36.

9 Милюков П.Н. Цели войны // Ежегодник газеты «Речь» на 1916 год. С. 31-32.

10 Милюков П.Н. Территориальные присоединения России // Чего ждет Россия от войны? С. 59-62; Милюков П.Н. Цели войны // Ежегодник газеты «Речь» на 1916 год. С. 38-46.

11 Милюков П.Н. Цели войны // Ежегодник газеты «Речь» на 1916 год. С. 46-56. 
нах $^{12}$. Такие увеличение российской территории укладывалось как в этнографическую, так и в оборонительную логику. Предполагалось объединение Польши (включая часть Силезии) в составе России и создание польской территориально-политической автономии ${ }^{13}$. Милюков также предполагал раздел Австро-Венгрии, создание Югославии и Чехословакии, соединенных «Славянским коридором» (80-100 км шириной и 200 км длиной), который, в свою очередь, разделял бы Австрию и Венгрию ${ }^{14}$.

К России по проекту Милюкова также присоединялась Кенигсбергская губерния (нынешняя Калининградская область), населенная 1,5 млн немцев. Кадетский лидер предлагал рассматривать ее как еще одну остзейскую губернию (наряду с Курляндией, Лифляндией и Эстляндией (современными Латвией и Эстонией) $)^{15}$. Туган-Барановский также настаивал на послевоенном открытии германского внутреннего рынка для российской сельскохозяйственной продукции: как хлебной, так и животноводческой ${ }^{16}$. Расчленение основной части Германии не считалось реалистичным, причем основной причиной называлось то, что это не соответствовало интересам Британии. Однако необходимым было установление послевоенной германской

12 Милюков П.Н. Территориальные присоединения России // Чего ждет Россия от войны? С. 49-52.

13 Милюков П.Н. Территориальные присоединения России // Чего ждет Россия от войны? С. 52-55; Милюков П.Н. Цели войны // Ежегодник газеты «Речь» на 1916 год. С. 86-87.

14 Милюков П.Н. Цели войны // Ежегодник газеты «Речь» на 1916 год. С. 90-108.

15 Милюков П.Н. Территориальные присоединения России // Чего ждет Россия от войны? С. 55-56.

16 Туган-Барановский М.И. Война и народное хозяйство // Чего ждет Россия от войны? С. 21-22. 
границы по Рейну, а также раздел колоний Германии между Британией, Францией и Японией ${ }^{17}$.

В целом, внешнеполитические задачи России в формулировке радикальных либералов не сильно отличались от тех, что озвучивали умеренные либералы, консерваторы, министры или дипломаты (хотя представители власти далеко не всегда могли сделать это публично). Западная граница России мыслилась примерно такой, какой стала граница СССР в 1945 г. (за исключением Польши). Однако, несмотря на масштабное перекраивание европейских и ближневосточных границ, на первое место либералами, тем не менее, сразу выдвигались задачи политических преобразований в самой России.

В самом начале войны, 23 и 24 июля ${ }^{18}$, московской городской управой и московским губернским земством было инициировано создание Всероссийского союза городов и Всероссийского Земского союза по помощи больным и раненым воинам, получившее одобрение императора. Союзы получали правительственные ассигнования, которые могли тратить по своему усмотрению без какой-либо отчетности. По самому названию, а также опыту русско-японской войны 19041905 гг. было ясно, что организации имеют временный характер и просуществуют лишь до окончания войны. Однако позднее уже отмечалась необходимость сохранения союзов после войны, причем они именовались «орудиями нашего политического творчества» ${ }^{19}$.

Приветствуя создание всероссийских общественных организаций, активист кадетской партии и со-

17 Милюков П.Н. Цели войны // Ежегодник газеты «Речь» на 1916 год. С. 90-128.

18 Даты приводятся по юлианскому календарю.

19 См., напр.: Гессен С.И. Идея нации // Вопросы мировой войны. C. 589 . 
трудник Всероссийского союза городов Н.Н. Щепкин в «Русских ведомостях» отмечал: «Это - только первый шаг в трудную для нас минуту» ${ }^{20}$. Вскоре газета уже писала, что именно общественная инициатива, а не бюрократические учреждения МВД могут помочь в деле о призрении семей воинов ${ }^{21}$. Еще дальше пошел октябристский «Голос Москвы», который в эти дни указывал, что правительство в России должно быть составлено «преимущественно» из среды общественных деятелей. Тональность октябристского рупора вполне соответствовала настроению «Русских ведомостей»: «Несмотря на всю важность европейских событий, нельзя упускать из виду и вопросы внутренней политики» 22 . 25 июля октябристский ЦК даже выпустил воззвание, в котором говорилось о необходимости послевоенного «усовершенствования внутреннего государственного порядка» ${ }^{23}$. Находившаяся на другом фланге от радикальных либералов умеренно-социалистическая газета «День» писала, что Россия «ждет от правительства твердых заявлений, что над родиной нашей встает заря новой свободной жизни» ${ }^{24}$. Примечательно, что подобные требования были озвучены в печати в самом начале войны и публиковались несмотря на установленный режим военной цензуры.

Для демонстрации единения власти и общества правительством было инициировано заседание Государственной думы 26 июля. Первоначально кадеты

20 Щепкин Н. Союз городов России // Русские ведомости, 10 августа 1914 г.

21 Русские ведомости, 14 августа 1914 г.

22 Политические слухи // Голос Москвы, 25 июля 1914 г.

23 Голос Москвы, 26 июля 1914 г.

24 День, 26 июля 1914 г. 
не планировали отдельного выступления ${ }^{25}$. Затем под давлением правого крыла партии соответствующее решение было принято, а первоначальный текст речи П.Н. Милюкова значительно смягчен. Но и после этого кадетский оратор не заявлял о поддержке правительства и не называл окончание войны сроком возобновления политической борьбы. Непосредственные цели войны Милюков формулировал следующим образом: «Мы ведем борьбу за освобождение нашей родины от иноземного нашествия, Европы и славянства от германского преобладания, <..> всего мира от невыносимого гнета постоянно растущих вооружений, разоряющих мирных тружеников <...> и вызывающих все новые и новые вооруженные столкновения». При этом «заветной целью», к которой страна стала бы ближе благодаря «тяжким испытаниям» войны, называлось «внутреннее обновление России» ${ }^{26}$. «Рссские ведомости» похвалили оборонческую позицию трудовиков и меньшевиков, но также ничего не писали о единении с правительством. Отмечалось лишь единение самой страны: «Перед лицом внешнего врага Россия едина» ${ }^{27}$.

В виде первоочередной задачи радикальные либералы ставили перед властью присоединение к общенациональному единству, что должно было выразиться в отмене национальных и религиозных стеснений, а также политической амнистии. Уже 3 августа 1914 г. кадетская газета «Русские ведомости» отмечала: «Возникшее перед внешней опасностью духовное единение разно-

25 Государственная дума. Созыв IV. Сессия II. Журналы совещания Государственной думы. СПб., 1914. С. 202.

26 Государственная дума. Созыв IV. Стенографический отчет заседания 19 июля 1914 г. Пг., 1914. Стб. 24-25. Подр. см.: Гайда Ф.А. Либеральная оппозиция на путях к власти (1914 - весна 1917 г.). М., 2003. С. 53-54.

27 Русские ведомости, 27 июля 1914 г. 
племенного населения России должно быть раз навсегда закреплено правовой организацией, обеспечивающей каждой народности ее место в общем отечестве, предоставляющей инородцам полноту гражданских прав и свободу национально-культурного развития. Никогда чувство государственности не было так сильно в населении России, как в настоящую минуту. Нужно дать ему простор, нужно устранить все искусственные преграды, стоящие на его пути, и оно явится для нас твердой, несокрушимой опорой в настоящей борьбе. Несовместимый с жизненными интересами государства узкий национализм распадается сам собой, он тает как воск от лица огня. Мы должны смело вступить на новый путь, на который нас ведет история» ${ }^{28}$. При этом газета критиковала рупор прогрессистской партии «Утро России», призывавшее отложить все внутренние вопросы до окончания войны. «Русские ведомости» отмечали, что «лозунг прекращения внутренней распри в стране» нельзя понимать «как призыв к прекращению внутренней жизни страны». Газета призывала поставить на повестку «жизненные задачи России огромной неотложной важности», понимая под ними политическую амнистию, еврейский и галицийский вопросы ${ }^{29}$. В связи со смертью председателя Государственного совета М.Г. Акимова и обсуждением возможных кандидатур на этот пост (назвались гр. А.А. Бобринский, И.Г. Щегловитов, А.С. Стишинский, П.Н. Дурново, гр. В.Н. Коковцов) «Русские ведомости» предлагали не спешить и не назначать какое бы то ни было лицо, ставшее «бьющим в глаза анахронизмом» ${ }^{30}$.

28 Там же. 3 августа 1914 г. См. также: Ковалевский М.М. Национальный вопрос и империализм // Вопросы мировой войны. С. 560-561.

29 Русские ведомости, 17 августа 1914 г.

30 Арсеньев К. Невероятные слухи // Русские ведомости, 15 августа 1914 г. 
В дальнейшем программа внутренних преобразований была дополнена требованиями, касавшимися местного самоуправления и школы. Предполагалась широкая реформа земства: его демократизация на основе всеобщего избирательного права, освобождение от опеки администрации, распространение на окраины страны. Либералы настаивали на создании волостного земства и поселкового управления, на земском обложении казенных и церковных земель, а также освобождении самоуправления от общегосударственных повинностей ${ }^{31}$. Реформа образования заключалась в отказе от классического принципа, децентрализации (развитии земской школы), введении всеобщего обучения ${ }^{32}$.

Сформулированная еще в самом начале войны программа получила законченное оформление в декларации Прогрессивного блока, опубликованной 25 августа 1915 г. При этом требование «министерства доверия» так и не было подкреплено согласованным списком кандидатов. Попытки власти идти на уступки в такой ситуации не могли принести положительного результата и лишь усиливали «министерскую чехарду». «Блок в сущности основан на фикции, что при настоящих условиях в России может быть правительство, не враждебное стране», - отмечал на заседании кадетского ЦК Ф.И. Родичев ${ }^{33}$. Кроме того, из-за внутренних противоречий парламентский блок так и не смог наладить законодательный процесс на основе

31 Шингарев А.И. Земская и городская Россия // Чего ждет Россия от войны? С. 183-209.

32 Знаменский С.Ф. Основные задачи в области образования // Чего ждет Россия от войны? С. 158-168.

33 Протоколы ЦК и заграничных групп конституционно-демократической партии. В 6 т. М., 1997-1998. Т. 3. С. 168. 
собственной декларации ${ }^{34}$. Эти обстоятельства подталкивали радикальных либералов к использованию деструктивных способов политической борьбы. Наиболее ярко эта особенность проявилась после 1 ноября 1916 г. - с началом «штурма власти».

19 ноября 1916 г. новый премьер-министр А.Ф. Трепов выступил с правительственной декларацией в Государственной думе. Он отметил, что правительство «всячески пойдет навстречу целесообразному <...> развитию» деятельности общественных организаций. Премьер заявил о срочной подготовке и проведении реформы городского самоуправления, введения волостного земства и снятии национальных и конфессиональных ограничений на получение образования. Кроме того, он известил депутатов о достигнутых в 1915 г. межсоюзнических соглашениях о передаче России после войны черноморских Проливов ${ }^{35}$. Однако, несмотря на это, никакого соглашения правительства и парламентского блока не состоялось. Декларация, как утверждали «Русские ведомости», «была встречена Думой холодно и не нашла в ней никакого сочувственного отклика» ${ }^{36} .16$ декабря лидер блока П.Н. Милюков в свой речи отказал правительству в доверии и потребовал дальнейших уступок думскому большинству ${ }^{37}$.

Оппозиционная активность русских радикальных либералов стала одной из важнейших причин Февральской революции 1917 г. Войдя в состав Времен-

34 Подр. см.: Гайда Ф.А. Ук. соч. С. 188-190, 207-209, 216-218, 247248.

35 Государственная дума. Созыв IV. Сессия V. Стенографические отчеты. Ч. І. Пг., 1916. Стб. 251-259.

36 Русские ведомости, 20 ноября 1916 г.

37 Государственная дума. Созыв IV. Сессия V. Стенографические отчеты. Ч. І. Стб. 1173-1177. 
ного правительства, либералы пытались реализовать заявленные в период войны задачи. Однако революционные перемены, вполне укладывавшиеся поначалу в рамки партийной программы, сразу поставили крест на возможностях достижения внешнеполитических целей. Если ранее это предполагалась сделать с опорой на Антанту, то уже весной 1917 г. Антанта перестала поддерживать любые идеи, связанные с расширением территории России (в первую очередь это касалось Проливов) $)^{38}$. Тем самым, радикально-либеральная программа потерпела крах, а страна оказалась перед лицом общенациональной катастрофы.

38 Игнатьев А.В. Русско-английские отношения накануне Октябрьской революции (февраль - октябрь 1917 г.). М., 1966. С. 158-164, 212-217; Демченко А.П. Военнополитическая программа Временного правительства России и позиция Великобритании // Межвузовская научная конференция «Россия в первой мировой войне: проблемы истории и историографии»: сборник докладов. 28 ноября 2014 г. СПб., 2015. С. 111-118. 